\title{
Bakens, drumpels en webbe: (Hervormde) Teologie as kreatiewe onderneming
}

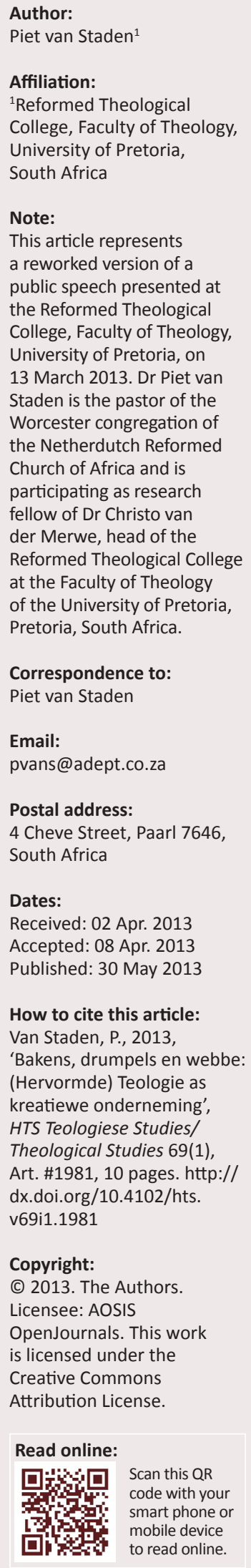

Beacons, thresholds and webs: Theology as creative endeavour. This article argues from the premise that theology is a creative undertaking. Nothing can be thought about God other than by thinking about people's experience and understanding of God. Theology therefore speaks objectively about God from the subjective experience of God and from testimonies about that experience. Such reflections and testimonies are expressed in language. However, the inherent constraints of vocabulary and formulation render any linguistic expression of such spiritual encounters incomplete. Theology is always seeking for new possibilities of expression in order to overcome the constraints. It stands to reason that the figurative mode of expression will be preferred to the concrete or factual register of language because figurative language is more suited to articulate the elusive spiritual experience of meeting God through faith. Signposts, thresholds and webs are employed here as metaphors to emphasise the creative aspect of theology within the context of a changing world. They represent the three phases in the socalled rites of passage described by anthropologist Arnold van Gennep and refined by Victor Turner into an abstract model employed in the understanding of all similar experiences of ritual transference. Here the model is applied to the church and its theology.

\section{Inleiding}

Die Nederduitsch Hervormde Kerk van Afrika (NHKA) word sedert die 69ste Algemene Kerkvergadering van 2010 deur 'n minderheid uit eie geledere verwyt dat hulle wesenlik van teologiese uitgangspunte en standpunte van die verlede afwyk. Dit hou verband met 'n besluit (54) van daardie vergadering waarin erken word dat die Kerk fouteer het deur in die verlede ' $n$ bepaalde politieke beleid teologies te regverdig (NHKA 2011a). Daar is selfs deur 'n aantal predikante en lidmate ' $\mathrm{n}$ status confessionis teen die Kerk uitgeroep waarin onder andere gehandhaaf word dat die Kerk en sy teoloë dwaal (vgl. Komitee van Steedshervormers 2012).

In hierdie bydrae word aangevoer dat die Kerk nie afwyk van 'n teologiese standpunt nie, maar juis trou is aan die aard van die teologiese tradisie wat kenmerkend is van die Kerk deur kreatief en verkennend in die teologiese besinning te werk te gaan.

Aan die hand van die drie begrippe 'bakens', 'drumpels' en 'webbe' word geargumenteer dat die teologie en eie aard (praktyk) van die Kerk aan liminaliteit onderhewig is. Laasgenoemde is ' $n$ begrip wat aan die antropologie ontleen is en in 'n abstrakte model funksioneer waarmee transformerende oorgange by individue en groepe beskryf en geïnterpreteer word. Die model onderskei drie fases in die oorgangsproses, naamlik die losmaking van die bekende struktuur en waardes, die oorgangstyd as 'n tussentyd 'op die drumpel' waar die ou identiteit nie meer geld nie maar 'n nuwe nog nie gedefinieer is nie en die reïntegrasie waar die personae liminae, die 'drumpelmense,' in 'n grondingsritueel met 'n nuwe status funksioneel in 'n strukturele web van verhoudings geïntegreer word.

Die struktuur van die artikel beeld in breë trekke die liminale proses uit. Die eerste deel bevat 'n bespreking van die bakens van die Hervormde teologie en dui aan hoe die teologie telkens progressief vorentoe beweeg deur in denke en toepassing te vernuwe. Die progressie impliseer 'n losmaking, maar nie noodwendig 'n diskontinuïteit nie, van die teologiese bakens van die verlede. Die tweede deel bevat 'n uiteensetting van liminaliteit en dui aan dat die kerk eienskappe toon van 'n organisasie wat vanweë eksterne invloede herhaaldelik deur liminale fases gaan en wat vanweë interne oorwegings (onder andere oortuiging of geloof) in werklikheid in 'n durende staat van liminaliteit verkeer. Die liminale fase word dikwels met kreatiwiteit en vernuwing geassosieer.

Die derde deel verwys na die strukturele en konseptuele web van verhoudings waarin die kerk en die teologie na afloop van die liminale proses geherintegreer moet word. Dit probeer om aan die 
hand van die begrip chaosteorie in die bestuurswetenskap die strukturele verhoudings nuut te konsipieer.

In die lig van die uitgangspunt dat die teologie 'n kreatiewe onderneming is, is enkele inleidende gedagtes oor kreatiwiteit hier gepas.

\section{Teologie as kreatiewe onderneming: Narratiewe gapings}

Kreatiewe denke word doelbewus gestimuleer wanneer oënskynlik onverwante sake op so 'n manier met mekaar verbind word dat nuwe verbande en insigte gegenereer word. Dit is ' $n$ vorm van dinamiese betekenisgenerering waartydens die onderbewussyn ekwivalensie registreer en verbindings lê tussen sake wat volgens logiese denkpatrone nie normaalweg met mekaar in verband gebring word nie. Hierdie ekwivalensie gee dikwels aanleiding tot innoverende oplossings vir probleme wat haas onoplosbaar gelyk het.

Teologiese besinning in die Reformatoriese tradisie gaan bewustelik van die primaat van die teks uit. Dit beteken dat die Bybel as ' $n$ versameling religieuse tekste die grondslag van die teologie vorm. Dit is nie slegs ' $n$ konfessionele standpunt nie, maar ook'n epistemologiese en hermeneutiese een. Daarom word hier enkele opmerkings oor die aard van (narratiewe) tekste gemaak.

Die begrip 'narratiewe gapings' (narrative gaps) is bekend. Dit verwys na gapings in die vertelling, ook bekend as ellipse. Iser (1980:55) verwys daarna wanneer hy stel dat geen verhaal ooit volledig in die fynste besonderhede vertel kan word nie. So iets sou 'n baie vervelige teks wees. Narratiewe gapings is eie aan die aard van narratiewe tekste en is 'n strukturele eienskap daarvan. Dit versnel die tempo van die verhaal, skep spanning, ondersteun die plot en betrek die leser by die vertelling. Skrywers kan sulke gapings aanwend om 'n bepaalde effek of doelwit te bereik en maak staat daarop dat lesers afleidings oor die narratiewe gaping sal maak of dit vanuit hulle verbeelding sal invul. Die werk van Ernest Hemingway is 'n goeie voorbeeld hiervan. Hy het die ysberg-teorie gehuldig waarvolgens die grootste deel van die struktuur van 'n verhaal onsigbaar moet wees (Wikipedia n.d.). Sy standpunt was dat die gehalte van 'n verhaal afhang van die gehalte van die dele wat weggelaat is. Dus, die ongeskrewe narratiewe gapings het betekenis en is net so deel van die teks as die geskrewe deel. 'n Bekende narratiewe gaping in die Bybel is die verlore jare van Jesus wat in die Lukas-evangelie voorkom. In Lukas 2:42 word vertel dat Jesus se ouers hom na die tempel gebring het toe hy 12 jaar oud was. Wanneer Jesus weer vermeld word, in Lukas 3:23, is hy reeds 30 jaar oud. Wat het in die 18 jaar tussenin gebeur? Elke leser vul sulke gapings met inligting. Die voorwaarde is dat die invulling met die strekking, inhoud en konteks van die betrokke teks moet strook en nie onrealistiese fantasmagorie sal insluit nie.

Die interpretasie van sulke tekste behels dus, om dit baie eenvoudig te stel, drie dinge:
- die bestudering en analise van die aard, inhoud en konteks van die teks met alle geldige metodes (Wat staan daar?)

- die nadenke en kommentaar oor dit wat in die geskrewe teks geartikuleer word (Wat beteken dit en waarna verwys dit?)

- die invulling van die narratiewe gapings (Wat is weggelaat?).

Die meeste hiervan is bekende aspekte van die eksegetieshermeneutiese proses. Volgens Bolton (2009) is die betekenismoontlikhede van narratiewe onuitputlik, juis vanweë narratiewe elisie. Die gedagte dat 'n narratief een vaste betekenis moet of kan hê, soos dikwels beweer word deur mense wat op 'n letterlike lees van die Bybel aandring, is beslissend van die hand gewys deur Gadamer, Jauss, Iser en ander eksponente van die filosofiese hermeneutiek en die resepsieteorie. Sandvoss (2011:238; kyk ook na Davey 2002; Kinoshita 2004) verwys na Iser se siening dat 'n teks se interpretasie mettertyd kan verander, al bly die teks dieselfde. Hieruit lei hy af dat die betekenis van literêre tekste deur die lesers gegenereer word.

Die gapings bring mee dat daar in en deur die teks ruimte vir meervoudige interpretasie geskep word. Reeds hierin word ons met die kreatiewe potensialiteit van die teks gekonfronteer, en dan het ons nog nie eens oor die aanwending van figuurlike taal soos metafore, vergelyking, allegorie en so meer gepraat nie. Voeg nog daarby die doelbewuste komposisie van die volledige teks as uitgebreide metafoor en dit is meteen duidelik dat dit 'n onbegonne taak is om so ' $n$ teks se betekenis eenduidig vas te pen. Ons kan dit selfs sterker stel: Die tekste verset hulle teen homogenisering en eenduidige interpretasie. Sulke betekenisgewende narratiewe daag die leser uit tot meer as net verstaan - dit loop uit op wat Gadamer (1960; kyk na Gander 2007:122-125) 'n versmelting van die leser se verstaanshorison met dié van die teks noem.

\section{Bakens}

Bakens is vaste punte wat dien as oriënteringspunte vir ons sosiale, ruimtelike, temporele en intellektuele posisie. Daar is bakens wat wys waarvandaan ons kom (terminus a quo), waarheen ons gaan (terminus ad quem), wie is ons (positiewe identiteit), wie is ons nie (negatiewe identiteit) en hoe ons dink. Roetepunte, word dit in GPS-taal genoem.

By die teologie geld die onderskeie vakdissiplines as bakens waarvan die koers en stand van navorsing afgelei kan word. Die teologie en die kerk bestaan egter nie geïsoleerd in die wêreld nie en kan ook nie, om Beyers (2013) se onderskeid tussen immanensie en transendensie in ' $n$ onlangse artikel aan te haal, tot suiwer transendensie vervlugtig word nie. Daar is altyd ' $n$ wyer konteks - die geskiedenis van die kerk, die land en die wêreld; die geloofstradisie; die ontwikkeling van idees en die tydsgees, die wetenskap en so meer. Oor hierdie wyer konteks skryf Oberholzer (1999:450): ‘Die groei van die kerk het negatief geword, ekonomies worstel hy om te bestaan, sy teologiese voorraad is in baie opsigte 
onbruikbaar, sy politieke erfenis in skerwe.' Hy (Oberholzer 1999:451) meen verder: 'Die pad van die Nederduitsch Hervormde Kerk hierdie eeu was 'n gebonde pad met min ruimte vir vry beweging en met min teologie.'

Oor die wyer konteks kan ons nie verder praat nie. Ons bepaal die aandag dus by die interne probleemkompleks van dogma en die Bybelwetenskappe.

\section{Skrif en belydenis}

Bybelwetenskaplikes is tradisioneel lugtig vir dogma. Dit is omdat dogma deur die geskiedenis ervaar is as die grootste bedreiging vir die vryheid van die Bybelwetenskappe om hulle werk te doen sonder dat daar beperking geplaas word op die toelaatbaarheid van hulle bevindinge en selfs op waarmee hulle besig mag wees. Tog, wanneer 'n mens oor Hervormde teologie moet praat en jy iets oor die geskiedenis en tradisie wil sê, is dit belangrik om die terrein van die sistematiese teologie te verken. Dit is so omdat die sistematiese teologie nie net sistematiserend met die spektrum van die teologiese ensiklopedie werk nie, maar ook evaluerend. Die sistematiese teologie het dus die funksie om nuwe denkrigtings en konklusies binne die teologie te toets sover dit hulle geldigheid aangaan en dit dan in te orden of uit te sluit. Die interdissiplinêre gesprek tussen die Bybelwetenskappe en die dogmatiek is belangrik vir die vasstelling van die eie aard van Hervormde teologie (vgl. Pelser 1985:346-349). Ek hanteer dus die Bybelwetenskappe en die dogmatiek in hierdie gedeelte saam omdat die wisselwerking tussen die twee inligting oor die teologiese tradisie van die Hervormde Kerk weergee. Die bespreking is uiteraard kursories.

Historiese teologie - 'n mens kan dit ook dogmengeskiedenis noem - trek 'n roetekaart op met die volgende roetepunte:

- die Ou-Testamentiese tyd

- die Nuwe-Testamentiese tyd

- die Patristiese tyd

- die Bisantynse tyd

- die vroeë en laat Middeleeue

- die Renaissance en die Kerkhervorming

- die modernisme en die kritiese teologie

- die postmodernisme.

Hierdie geskiedenis behels kennelik 'n vermenging van teologiese en filosofiese kategorieë, en dit kan nie anders nie vanweë die wisselwerking tussen die teologie en die tydsgees. Binne elkeen van hierdie tydperke was daar weer verskillende teologiese nuanses en trajekte. Veral van belang is dat daar 'n veelvoud teologieë in die Bybel voorkom en die aanduiding dat teologiese trajekte in die Bybel self gewysig en vernuwe is. Ruimte ontbreek om in besonderhede daarop in te gaan en daarom bepaal ek my by 'n wending in die eksegeties-hermeneutiese benadering in die teologie van sowat 30 jaar gelede, wat eksemplaries funksioneer vir ander sodanige gevalle.

\section{Die Bybelwetenskappe}

Die aanduiding van konflik tussen die Bybelwetenskappe en leerstellige posisies vind ons in ' $n$ artikel wat Loader in 1978 geskryf het, met die titel 'Gedagtes oor gekontroleerde eksegese'. Loader verwys na die fenomenale ontwikkeling in die taalkunde oor die voorafgaande twee dekades, dit wil sê vanaf ongeveer 1960. Hy praat oor die Bybel as 'n versameling geskrewe literêre werke wat wel God se woord is, maar tegelyk ook menslike geskrifte in menslike tale. Hy voer die insig oor die menslikheid van die Bybel na Karl Barth terug (Loader 1978:1).

Waarom vind Loader dit nodig om hom in 'n artikel oor eksegese byna apologeties op 'n ikoon van die teologie te beroep - wat ook in Hervormde teologiese kringe hoë aansien geniet het - vir sy insig in die menslikheid van die Bybelse geskrifte? Die antwoord lê in die weerstand wat hier te lande veral uit Gereformeerde kringe maar ook uit die Hervormde kerk self gekom het teenoor die teks-immanente eksegese as eksegetiese benadering (vgl. Loader 1978:3). Loader beskou die weerstand en kritiek as 'n misverstand, enersyds vanweë wantroue jeens vernuwing en oningeligtheid oor wat die nuwe rigting werklik sê en andersyds vanweë die foutiewe afleiding dat die eksegese deur die verabsolutering van een spesifieke metodiese aspek gekaap word. Hy ontken (Loader 1978:4) dat hier van so'n metodemonisme sprake is. Wanneer hy verder uitwerk hoe die pluraliteit metodes lyk waarmee die eksegeet die teks benader, lê Loader (1978) klem op die kwessie van voorveronderstellings en formuleer soos volg oor die verhouding tussen die eksegese en die dogmatiek:

Eerstens is die belydenis dat ons in die Bybel met Gods woord te doen het, nie 'n towersleutel vir die interpretasie nie. Die menslike van die Bybel maak dat ons ons moet oriënteer aan die feit dat ons met gewone literêre produkte te doen het. Dit beteken dat ons nie van 'n teologiese voorveronderstelling as model vir die eksegese mag uitgaan nie ... Dit beteken verder dat die eksegese nie vanuit die dogmatiek beoefen mag word nie, maar omgekeerd moet die dogmatiek wel op grond van die eksegese beoefen word. (bl. 6)

Een van die gevolge van teks-immanente eksegese was dat dit sekere foutiewe uitgangspunte in die geldende eksegeties-hermeneutiese proses ontbloot het. 'n Mens kan vermoed dat dít waarskynlik meer as enigiets anders tot die weerstand aanleiding gegee het. Dit is moeilik vir teoloë en predikante om te verneem dat die manier waarop hulle die teks interpreteer en gevolglik ook die manier waarop hulle preek skielik as foutief uitgewys word - veral as dit gaan oor die manier waarop Christus as die vervuller van die Ou Testament verstaan word. Loader (1978) wys uit dat die gedagte van Christus as die vervuller van die Ou Testament 'n saak van geloof is en as 'n geloofsveronderstelling of voorveronderstelling by die uitleg van die Ou Testament funksioneer:

Hierdie geloofsveronderstelling mag nie die metode waarvolgens ons ons wetenskaplike uitleg doen, bepaal nie. Dit sou beteken dat ons, in stryd met wat ons elders in die Hervormde tradisie afwys, die Christelike wetenskap beoefen. In Hervormde kringe word daar graag aanvaar dat wetenskaplike metode in geen 
dissipline deur die geloofsveronderstellings van die beoefenaar bepaal mag word nie. Maar ons wyk maklik hiervan af wanneer ons met die Bybelwetenskap te doen het. (bl. 12)

Loader (1978:12) bespreek 'n aantal maniere waarop die vervullingswerk van Christus 'sedert eeue tot vandag toe hermeneuties funksioneer':

- die belofte-vervulling-skema waarvolgens die tekste van die Ou Testament 'as blote voorspellings van of vingerwysings na Christus beskou' word en die betekenis wat die gedeelte in eie reg dra, misken of gewysig word (vgl. Loader 1978:12-13)

- die allegorese, waarvolgens daar'n dieper, geheimsinnige betekenis agter die teks lê en wat weereens die betekenis van die teks in eie reg ignoreer (vgl. Loader 1978:13)

- die tipologiese sisteem, waarvolgens persone, instellings en gebeure in die Ou Testament as tipes of voorlopers van Christus beskou word en wat in beginsel soos die beloftevervulling-skema funksioneer (vgl. Loader 1978:13-14).

Die probleem met hierdie benaderings is dat dit impliseer dat die Ou Testament alleen betekenis het vir sover dit die Nuwe Testament eggo. Volgens Loader (1978) word die historiese karakter van die $\mathrm{Ou}$ Testament daarmee misken:

Dit gaan nie hier om die theologoumenon dat Christus die middelpunt van ons teologie en prediking is nie, maar om die kunsmatige wyse waarop hierdie gegewenheid as 'n hermeneutiese model gebruik word. Dit wil sê die feit dat Christus in die sentrum staan, word gebruik as 'n sleutel om vas te stel wat die Ou Testament vir ons te sê het. (bl. 15)

Wat is die oplossing? Loader (1978; kyk ook na Oberholzer 1990:652-654) formuleer dit soos volg:

In plaas van 'n bepaalde Nuwe-Testamentiese teks of tema moet die hele Nuwe Testamentiese kerygma ... op die betrokke OuTestamentiese passasie van toepassing gemaak word ... Daarom moet die lig van Christus retrospektief ... teruggegooi word op die spesifieke gedagtepatroon wat ons onbevange eksegeties vasgestel het. (bl. 16)

Die weerstand teen die teks-immanente benadering met die dogmatiese implikasies daaraan verbonde word verder deur Van Aarde opgeneem wanneer hy in 'n latere artikel die beskuldiging teen proff. W.S. Vorster en J.A. Loader bespreek, naamlik dat hulle eksponente is van teologiese liberalisme wat 'n aanslag teen die Skrifgesag lei (Van Aarde 1981:6). Volgens Van Aarde is die sake wat hier ter sprake kom die inspirasieleer (1981:7-8), die verband tussen die Woord van God en die Bybel (1981:8-12), die openbaringsgeskiedenis in die Bybel (1981:12-15). die duidelikheid of 'selfevidensie' van die Skrif wat uitgedruk word in die gedagte dat die Skrif sigself verklaar (1981:15-16) en laastens die kanonbegrip (1981:16-19).

Dit is met een oogopslag duidelik dat die besware dogmaties geïnspireer is. Van Aarde (1981:8) verwys na die theologoumena [teologiese opinies] oor hierdie soort aangeleenthede as 'suiwer geloofs-apriories van aard'. Wanneer teologiese opinies die manier bepaal waarop teoloë die Bybel interpreteer, is dit onwetenskaplik. Ons kan bysê dat dit waarskynlik on-reformatories is vir sover die
Reformasie die gees van die Renaissance adem en nie as ' $n$ outoritatiewe teologies-ideologiese sisteem beskou word nie.

\section{Die belydenis}

Die Hervormde teologie se benadering tot die belydenis word uitgedruk in 'n opmerking deur Velthuyzen (1984:84; vgl. ook Koekemoer 1995:879) dat die belydenisskrifte dokumente is wat nie losgemaak kan word van die situasie waarin hulle ontstaan het nie, en 'daarom sal enige poging om hierdie belydenisskrif voor te stel as 'n tydlose dokument, die belydenis as sodanig 'n onreg aandoen.' Hieruit lei Velthuyzen (1984:85) af dat die belydenisskrifte van die kerk geëksegetiseer moet word en dat die woorde en nuanses daarvan nie met ewigheidswaarde beklee moet word nie (kyk ook na Oberholzer 1993:883).

Met betrekking tot die Nederlandse Geloofsbelydenis (NGB) se uitsprake in artikels 2-7 oor die Skrif, verwys Velthuyzen (1984:86) na die Gereformeerde tradisie wat op grond hiervan die Heilige Skrif aan die Woord van God gelykgestel het. Dit impliseer dat die Skrif in alle sake, insluitend die historiese, argeologiese, geologiese en natuurwetenskaplike, betroubaar moet wees. Daarom is enige vorm van kritiese navorsing oor die Skrif volgens hierdie beskouing taboe (1984:86). Hierdie opmerking van Velthuyzen is belangrik aangesien dié soort Skrifbeskouing enige teologiese aktiwiteit soos ons dit ken, onmoontlik maak. Die Hervormde Kerk het nooit hierdie tipe Skrif- en belydenisbeskouing ondersteun nie. Velthuyzen (1984) formuleer soos volg:

... die feitelike onfeilbaarheid van die Skrif (met ander woorde, die volkome historiese en feitelike juistheid) [kan] net met skouspelagtige breingimnastiek volhardend verdedig ... word. Die kritiese wetenskap het aangetoon dat so iets as die eenheid van die Skrif ' $n$ mite is; dat die klassieke reformatoriese slagspreuk sacra scriptura sui ipsius interpres, nie diensbaar kan wees in die sin dat teenspraak en on-effenhede in die Skrif daarmee uit die weg geruim kan word nie en dat dit getuig van rasionalisme wanneer dit tog gepoog word. (bl. 89)

Dreyer (1985:380) verwys in 'n artikel na Ebeling se stelling dat die blote ondertekening van 'n belydenisformulier nie noodwendig ' $n$ aanduiding is dat die ondertekenaar se beskouing in ooreenstemming met die belydenis is nie en stel dan: 'Belydenis is nooit 'n statiese gebeure nie, maar ' $n$ dinamiese gebeure binne die tyd.' Op die vraag waar die primêre gesag van die verkondiging lê, skryf Velthuyzen (1985:371) elders dat die Kerk vasgevang is in 'n denksirkel - die belydenis is te alle tye ondergeskik aan die Skrif, maar dit is tog die belydenis wat bepaal hoe die Skrif uitgelê mag word. Die kerk en die teologie moet gedurig 'n balans vind in hierdie spanning (kyk ook na Pelser 1985:349; Smith 1985:362).

Dit blyk dus dat daar vantevore reeds spanning in die Hervormde Kerk was wanneer 'n kerndissipline soos die Bybelwetenskappe vernuwing ten opsigte van uitgangspunt en metode ondergaan en die resultate ' $n$ invloed op die dogmatiese a priori van die kerk het. Die Geyser-saak is ook 'n bekende baken in dié verband (kyk na Dreyer 1999:233- 
235). Die resente beskuldiging van dwaalleer aan die adres van akademici by die fakulteit is ' $n$ herhaling daarvan.

Sowat drie dekades gelede - vanaf die 1980's - het nuwe klemtone in die ondersoek na antieke tekste na vore getree. Hierdie ondersoekmetode staan as die sosiaalwetenskaplike interpretasie van tekste bekend en behels die toepassing van abstrakte modelle uit die sosiale wetenskappe op die teks ten einde nuwe inligting na vore te bring. Die gebruik van sulke modelle bevestig en beklemtoon die menslike aspek van die tekste van die Bybel sonder om die oortuiging aan te tas dat die tekste ook getuig van 'n outentieke godservaring en in daardie sin geïnspireerd en gesaghebbend is. Baie van die onlangse kritiek teen die werk van teoloë in die Kerk het myns insiens te doen met 'n onvermoë en soms selfs moedswilligheid om hierdie onderskeid te registreer en te probeer verstaan. Soos die geval 30 jaar gelede was, word die teoloë aangeval en van liberalisme en kwade bedoelings met die kerk beskuldig, terwyl die rede daarvoor waarskynlik weereens is dat dit bepaalde dogmatiese voorveronderstellings moeilik houdbaar maak en uiteindelik korrigerend op sekere praktyke in die kerk inwerk.

\section{Bybels-Reformatoriese teologie}

Die begrip 'Bybels-Reformatoriese teologie' kom in die Kerkorde van die Nederduitsch Hervormde Kerk van Afrika (NHKA 2011b) voor by Ordereël 2.1.6.1 (c) en Ordinansie 3.4.2 (vii) (b en d). Die kerk het dus amptelik 'n etiket aan sy teologie geheg. Daar is egter nêrens in die amptelike stukke 'n omskrywing of naderbepaling van wat met die etiket bedoel word nie.

In sy bydrae tot die publikasie 20ste eeu Hervormde teologie spreek Van Zyl (1999) hom soos volg uit oor die teologie:

Daarom moet teologie altyd nader bepaal word as kerklik, of Christelik, of Bybels-Reformatories. Ook ons teologie is 'n ernstige poging om dit in die Bybels-Reformatoriese tradisie te beoefen, want 'n Christelike kerk kan nie 'n amptelike, offisiële teologie hê, sonder dat vryheid van ondersoek ernstig aan bande gelê word nie. (bl. 406)

Dit is onduidelik of hy dit in ' $n$ positiewe of negatiewe sin bedoel. As dit positief bedoel is, beteken dit dat hy die 'adjektief,' soos hy dit noem, óf nie sien as 'n beperking op die teologie nie óf dit wel sien as beperkend in die sin van rigtinggewend, en dit dan as noodsaaklik beskou. In sy bespreking van die voornoemde adjektiewe lê hy dit soos volg uit (Van Zyl 1999):

Die Bybelse adjektief is belangrik omdat dit die enigste outentieke getuienis is van die menswording van God in Jesus Christus ... Die Reformatoriese adjektief is belangrik omdat dit getuig van die wyse waarop die Reformatore die Bybel verstaan het, naamlik as die skynbaar teenstrydige, onbegryplike werklikheid en waarheid dat die oppermagtige God 'n mens kan word sonder om God se soewereiniteit prys te gee, dat God tot ons mense kan praat deur die mensewoorde van hulle wat van God getuig in die woorde van die Bybel, deur die krag en verligting deur die Heilige Gees. (bl. 406)
Hoewel dit mooi op die oor klink, is die formulering wasig en verhul dit die problematiek van vooringenomenheid in teologiserende taal.

Van Zyl gee heelwat aandag aan die versoeningsleer van Karl Barth. Hy beskou Barth se dialektiese benadering tot die teologie as 'n teruggryp na die Reformatoriese teologie en hoewel hy waarsku dat die teologie nie verabsoluteer moet word nie, meen hy dat die 'handhawing van die kardinale geloofswaarhede soos deur die Reformatore verwoord, voorwaarde is vir die voortbestaan van die Protestantisme' (Van Zyl 1999:411). Hy meen dat die solus Christus-belydenis die basis van die reformasie asook van die versoeningsleer van Barth is. Daarom is Barth se siening van groot belang vir die kerk. Tog sluit hy sy bydrae af met 'n naskrif (1999:419): 'Dit is my oortuiging dat die neerslag van die Dialektiese Teologie, à la Barth, in ons teologie maar uiters dun is.'

Op talle ander plekke word na die Hervormde teologie as Bybels-Reformatoriese teologie verwys, asof almal presies weet wat daarmee bedoel word. Dit is egter nie die geval nie. Daar is ' $n$ implisiete en miskien selfs intensionele vaagheid aan die begrip, siende dat daar nêrens'n bloudruk bestaan van presies wat daaronder verstaan moet word nie. Van Wyk wy hoofstuk 3 van sy proefskrif, getitel 'Bybels-Reformatoriese Teologie', aan 'n bespreking en naderbepaling van die begrip. Hy stel verskillende teoloë aan die woord en maak uiteindelik 'n sintese van hulle standpunte. Dit is die mees volledige omskrywing waarvan ek bewus is (kyk ook na Pont 1999:201-205).

\section{Opsommend oor die bakens}

Opsommend kan gestel word dat die Hervormde Kerk by monde van sy teoloë en amptelike vergaderings konsekwent die standpunt handhaaf dat sy teologie-beoefening vanuit die primaat van Skrif gevoer word en dat die dogmatiek nie vir die Bybelwetenskappe voorskriftelik kan wees nie. Tegelyk word die binding aan die belydenisskrifte bevestig en is daar voorgeskrewe wyses waarop verstellings aan die belydenis van die kerk gedoen kan word indien eksegetieshermeneutiese resultate dit sou noodsaak. Hier wil ek pertinent verwys na 'n onlangse artikel van Beukes (2012:6) in Die Hervormer waarin hy myns insiens korrek uitwys dat daar 'n onderskeid tussen die werkterreine van die teologie (navorsing) en die Kerk (verkondiging) is. Die teologie maak sy resultate deur publikasies, besprekings en interne debat bekend. So word standpunte in die smeltkroes van die teologiese debat heroorweeg, verfyn en hersien indien nodig. Sulke teologiese resultate en standpunte is nie aan die geloof van die teoloog gelyk te stel nie. Dit is daarom heel onvanpas dat teoloë vanuit kerklike kringe vir hulle teologiese werk aangekla en verketter word. Kritiese opmerkings oor die belydenisskrifte geld in hierdie verband nie as 'n verwerping nie, maar as deel van die teologiese proses. Kerklike leiers behoort hulle teoloë teen sulke klagtes te beskerm, anders word dit vir hulle onmoontlik om hulle werk te doen. 
Die term Bybels-Reformatories as tipering van die Hervormde Kerk se teologie is 'n beskrywende term om die Kerk se bewustelike binding aan die Skrif en die belydenis te bevestig, maar wat dit presies beteken berus meer op aanvoeling as op die helderheid van definisie. Dit opereer ook dikwels in die kerk dogmaties om sogenaamde vrysinnige of afwykende teologiese standpunte en gevolgtrekkings af te maak (kyk ook na Van Aarde \& Pelser 2001:22). Indien die kerk meer beheer oor sy teoloë wil uitoefen, maar dan ook oor wat die lidmate glo, sal punt vir punt geefinieer moet word wat BybelsReformatories behels. Sodanige afbakening sou egter direk indruis teen verkennende teologie as 'n unieke eienskap van die Hervormde Kerk en teen die implisiete veronderstelling dat teologiese uitsprake voorlopig is. Hierop berus juis die Hervormde teologiese tradisie van duldbare verskeidenheid.

\section{Liminaliteit}

Die term 'liminaliteit' is afgelei van die Latynse woord limen, wat drumpel beteken. Dit is die eerste keer in 1909 deur die antropoloog Van Gennep ([1909] 1960) gebruik om die sielkundige proses te beskryf wat plaasvind wanneer mense deur middel van rituele 'n bepaalde statusverandering ondergaan. Sulke oorgangsrituele verloop meestal in drie fases, wat bekend staan as die losmaking (preliminale fase), tussentyd (liminale fase) en herintegrasie (postliminale fase). Turner (1969:94) beskryf die fases soos volg:

- Losmaking behels simboliese gedrag wat aandui dat die individu of groep losgemaak word van 'n vroeëre vaste posisie in die sosiale struktuur of van 'n toestand of status, of beide.

- Tydens die tussentydse liminale fase word die kenmerke van die kandidaat dubbelsinnig - hy of sy beweeg deur 'n kulturele gebied met weinig of geen van die kenmerke van die vroeër of komende toestand nie.

- Tydens die derde fase (van herinsluiting) word die ritueel voltooi. Die individu of groep is weer in 'n stabiele staat en bekom as gevolg daarvan regte en verpligtinge teenoor ander wat tot 'n duidelik gedefinieerde strukturele tipe behoort.

Beech (2010:288-290) beskryf liminaliteit as 'n dialogiese konstruksie van die self deurdat die identiteit in drie fases, naamlik eksperimentering, refleksie en herkenning, herkonstrueer word. Tydens die liminale fase word die selfkonsep ernstig ontwrig (2010:296). Die proses verloop deur vyf fases, te wete (1) 'n snellergebeure, wat te doen kan hê met organisatoriese verandering; (2) die liminale persona word struktureel onsigbaar en beklee 'n paradoksale identiteit; (3) sosiale skeiding vind plaas deurdat die liminaris as 'onrein' of 'buite perke' beskou word; (4) die liminaris het geen regte nie en moet opdragte gehoorsaam; en (5) die liminaris dink na oor die verhouding met die gemeenskap en ondergaan 'n identiteitsrekonstruksie (Beech 2010:297-298). Beech (2010:297) vind in hierdie psigologiese proses sterk parallelle met organisatoriese liminaliteit.

Die liminale fase verwys spesifiek na die toestand wanneer die persoon van die vorige status losgemaak is, maar nog nie in die nuwe status bevestig is nie. Vanweë die onseker staat word die toestand dikwels vergelyk met die dood, om in die baarmoeder te wees, om onsigbaar of in duisternis te wees, om dubbelslagtig te wees. Persone in ' $n$ liminale toestand word dikwels voorgestel as sou hulle niks het nie - geen status, eiendom, rangtekens of enigiets wat hulle van ander persone in die liminale groep kan onderskei nie. ' $n$ Voorbeeld hiervan is die Islam-pelgrims wat die hadj bywoon. Almal dra dieselfde ongedifferensieerde wit kleed sodat enige sekulêre status of rang vir die duur van die pelgrimsritueel verberg en opgehef word. Drumpelmense se gedrag is passief en nederig, hulle moet die instrukteurs onvoorwaardelik gehoorsaam en arbitrêre straf aanvaar sonder om te kla. So word hulle gereduseer tot ' $n$ toestand waar hulle omvorm en toegerus kan word vir die nuwe status wat gaan volg. Nuwelinge wat saam die liminale proses ondergaan, ontwikkel 'n sterk gevoel van kameraderie, gelykheid en eenheid van doel (vgl. Turner 1969:95).

Voorbeelde van metaforiese taal uit die Bybelse tradisie wat liminaliteit simboliseer, is die volgende: die graf, die wildernis en die uittog (Franks \& Meteyard 2007:218-220); vreemdelinge en bywoners in die wêreld; die pelgrim; die reisiger; iemand wat geen plek het om sy kop neer te lê nie; Wie is my moeder en my broers? (Mark 3:33); ou mens nuwe mens; saam met Christus gesterwe ... saam met Hom sal lewe (Rom 6:8); deur die doop in die dood begrawe word (Rom 6:4); die teken van Jona (Matt 16:4 en Luk 11:29); Jesus wat gesterf het, begrawe is, neergedaal het na die hel, op die derde dag opgestaan het, opgevaar het na die hemel (kyk na die Apostolicum, kyk NHKA s.a.) (vgl. Turner 1969:107). In ons kerklike tradisie vind ons moontlik 'n lang uitgerekte oorgangsritueel in die kinderdoop as losmaking, die kategesetyd as liminale fase en die belydenis van geloof as die herintegrasie met 'n nuwe status. Die beroep of verkiesing van ampsdraers (sneller), die oorweging (liminale tyd) en die bevestiging (grondingsritueel) kan ook as rituele oorgange geld.

Turner (1969:25) verbind liminaliteit met die begrip communitas. Dit is iets anders as die gemeenskap (societas). Communitas is nie gewone buurmansbestaan nie. Dit het 'n eksistensiële kwaliteit wat die totale mens in 'n verhouding met die totale ander mens betrek. Dit besit ook 'n aspek van intensionele potensialiteit. Verhoudings word nie uitgedruk in strak belynde terme nie, maar as moontlikhede wat gerealiseer kan word. Communitas produseer kuns en religie eerder as wetlike en politieke strukture. Dit kom tot stand in die tussenruimtes van strukture, op die drumpels, op die periferie van strukture, op die kantlyn, van onder die strukture, in die ondergeskikte (Turner 1969:128). In die bestuurswetenskappe staan dit bekend as 'vennootskappe' of 'spanne' wat die konvensionele organisatoriese grense toets en uitdaag (kyk na Sturdy, Schwarz \& Spicer 2006:935). Charniawska en Mazza (2003:272) verwys na Van Gennep en Turner se beskrywing dat liminaliteit 'n gevoel van vryheid en kreatiwiteit by deelnemers kan teweegbring, 'n besondere ervaring van gemeenskaplikheid (communitas - P.v.S.). 
Anders as Beech hierbo, meen hulle nie dat die 'in limbo' ervaring met gedeelde identiteit te doen het nie, maar met ' $n$ gedeelde sin van 'alterniteit,' van anders wees (Charniawska \& Mazza 2003:273).

Communitas word deur menslike vermoë daargestel en sluit rasionaliteit, intensionaliteit en geheue in. Tog is daar iets magies aan, iets wat die normale patrone en grense van verhoudings oorskry (vgl. Waskul 2005:52). Dit word as heilig beskou, want dit oorspan die norme van normale strukturele en institusionele verhoudings en bring uitsonderlike vermoëns na vore. In religieuse taal sou ons dit aan die werking van die Heilige Gees toeskryf.

Geen samelewing kan behoorlik sonder die dialektiek tussen struktuur en communitas funksioneer nie. Turner (1969:132; vgl. Beech 2010:288; Sturdy et al. 2006:932) wys daarop dat die spontaniteit en direktheid van communitas nie vir lank gehandhaaf kan word nie. Hy onderskei tussen eksistensiële of spontane communitas, normatiewe communitas waar sosiale sisteme tot stand gebring word en ideologiese communitas wat geld by utopiese gemeenskapsmodelle wat op eksistensiële communitas gebaseer is. Normatiewe en ideologiese communitas bestaan reeds binne die domein van struktuur. Dit kom voor asof alle spontane communitas uiteindelik regressief in strukture en reëls omsit.

In teenstelling met Turner word liminaliteit op ander gebiede nie as tydelik beskou nie, maar as durend, gelyktydig met en binne-in die normale strukturele grense (vgl. Cook-Sather 2006; Lindsay 2010; Charniawska \& Mazza 2003:272,284)

\section{Opsommend oor liminaliteit}

Die drie begrippe bakens, drumpels en webbe simboliseer die gang van die Kerk deur die geskiedenis as 'n iteratiewe oorgangsproses:

- 'Baken' is die aanduier van die struktuur van die teologiese tradisie en die geskiedenis van die kerk, en die verwagtingshorison (Jauss 1982) wat daaruit voortkom. Die teologie moet sigself telkens weer in belang van kreatiewe teologiese diskoers en herstrukturering van daardie struktuur losmaak. Dit is die eerste stap van die driedelige oorgangsritueel.

- 'Drumpel' is die aanduier van oorgange tussen die oue en die nuwe, tussen tradisie en nuwe insig, tussen struktuur en anti-struktuur. Dit staan vir die vloeibare tyd wanneer die teologie losgemaak is van die tradisie en nog nie nuwe koers en gestalte gevind het nie. Dit verteenwoordig die tweede stap in die oorgangsritueel.

- 'Web' is die aanduier van die aard van die strukturele verhouding met talle ander dissiplines en oortuigings waarin die teologie na elke liminale fase geherintegreer moet word. Dit staan vir die interne netwerk van vakdissiplines en kategorieë in die teologie, asook die eksterne netwerk van beïnvloeding in die verhouding met ander vakrigtings soos die menswetenskappe, die natuurwetenskappe en so meer. Dit verteenwoordig die derde stap in die oorgangsritueel, naamlik herintegrasie of gronding.
Dit blyk dat liminaliteit as verskynsel soos dit in oorgangsrituele werk 'n nuttige konsep is om te beskryf hoe die kerk in die wêreld funksioneer en hoe die proses aangewend kan word om die essensiële dinamika van kerkwees in stand te hou.

Charismatiese kerke slaag daarin om hulle eredienste so in te rig dat dit tot die belewing van liminaliteit en die generering van communitas lei. Elke erediens is 'n klein ritueel van losmaking, die ervaring van liminaliteit en herintegrasie. Dit wek geweldige energie op. Dit wil egter lyk asof die charismatiese kerke nie die struktuur het waarbinne die communitas wat opgewek is, kan opereer nie. Dit gaan uiteindelik daar oor die najaag van die liminale energie wat so te sê verslawend op die deelnemers inwerk.

Hierteenoor vertoon die hoofstroomkerke 'n onvermoë om die transformerende krag van die oorgangsrituele in hulle sterk gevestigde strukture te verstaan en te benut. Trouens, die oorontwikkelde strukturele aspek van hierdie kerke ontlok weerstand teen enige vorm van antistrukturele gedrag, soos byvoorbeeld die liminale fase van oorgangsrituele. Binne die nuwe tydsgees verklaar dit waarskynlik die geweldige verlies aan lidmate - daar is doodeenvoudig geen ruimte vir die verbeelding en die ervaring van communitas in sulke dominerende strukture nie. Die liminale gapings is afgesluit en ontoeganklik. Tog is die liminale ervaring klaarblyklik wat mense nou nodig het. Dit bevestig ' $n$ opmerking wat die bekende antropoloog Mary Douglas reeds in 1973 gemaak het, naamlik dat kerke geneig is om rituele te verminder terwyl dit andersom moet wees, aangesien mense 'n diepgesetelde behoefte aan die energieskeppende prosesse van rituele het (vgl. ook Van Staden 2001:587). Douglas (1973:154) wys trouens uit dat die jeug se anti-ritualisme gemik is teen rituele van differensiasie (strukturele onderskeide), maar dat rituele van entoesiasme gewild is. Dit sal interessant wees om 'n deeglike ondersoek na entoesiasme in die vroeë kerk te sien wat die model van rituele oorgange betref (vgl. Van Aarde \& Groenewald 2006).

Hierin lê daar 'n uitdaging vir die kerk. Kan daar binne die Bybels-Reformatoriese teologie vir die aktivering van liminale energie ruimte gevind word? Indien nie, sal die kerk vermoedelik sy kreeftegang bly gaan.

\section{Webbe}

In die Inleiding is aangedui dat die studie iets wil verbeeld van die oorgangsritueel met drie stappe, naamlik die losmaking van die bekende, die liminale transformasie en die herintegrasie in die struktuur. Die laaste deel van die studie gaan dan oor webbe as simbool van die verhoudings waarin die teologie en kerk hulle bevind. Die verhoudings het te doen met strukture - sowel konkreet as abstrak. Ons het hierbo reeds gesien dat daar 'n dialektiek tussen die liminale communitas en die gewone sosiale en organisatoriese strukture (societas) moet wees. Mense leef in die struktuur. Die liminale energie moet operasioneel in die sosiale struktuur ontlaai word. Maar hoe lyk hierdie struktuur? Watter soort verhoudings bestaan daarin? Het dit die vermoë om die energie wat in ' $n$ liminale oorgang gegenereer is, operasioneel 
te gebruik? Of sal daardie energie as oortollig, gevaarlik en onaanvaarbaar uit die sisteem gekanaliseer word?

Anders gestel: Bestaan die kerk om die struktuur in stand te hou? Is daar enigiets in die kerk oor wat ruimte laat vir communitas of is dit suiwer societas, institusionele skroot? Moet die kerk gedekonstrueer word, afgetakel word, sodat dit hersaamgestel kan word in 'n nuwe formaat waarin die energerende krag van God se Gees en die menslike ervaring van gemeensaamheid en alternatiwiteit die oorspronklike passie herstel? Kortom: Kan die kerk gerehabiliteer en geresussiteer word? En op watter manier?

Daar is reeds verwys na die dominerende sosiale en organisatoriese strukture wat in die meeste gevalle nie alleen as gegewe aanvaar word nie, maar ook as noodwendig. Waarom word dit so aanvaar? Die rede hiervoor is tweeledig:

- Eerstens is daar die mens se objektiverende omgaan met die werklikheid waardeur mense hulle ondergeskik stel aan die strukture wat hulle self geskep het (vgl. Van Staden 1991:60).

- In die tweede plek geld in die sosiologie die funksionalistiese beskouing van die samelewing as 'n sisteem in ekwilibrium (vgl. Van Staden 1991:114-120). Dit is ook in ooreenstemming met die wetenskaplike paradigma van Newton en Descartes (vgl. Tiplady 2003:1). Hierdie beskouing bevestig die dominansie van strukture.

Dit blyk dat die kerk nie die enigste instelling is wat as 'n mislukte organisasie met sloping gekonfronteer word nie. Küpers (2011:45) dui aan dat verskeie organisasies aan verandering blootgestel is. Hulle gaan deur oorgangstye met hoë vlakke van ongeborgenheid, onsekerheid en wanorde, en hulle bestaan is in die weegskaal. Die veranderings vereis dat organisasies op verskillende uitdagings moet reageer deur te transformeer en te herstruktureer terwyl hulle hul identiteit en integriteit behou. Boonop raak organisasiestrukture al hoe meer ruimtes van liminaliteit en moet die lede daarvan vir liminale bewegings paraat wees. Liminaliteit, as ' $n$ beweging deur oorgangsruimtes en 'n toestand van tussenin wees, bring nuwe waardes, gedrag, sosiale dinamiek, funksies en strukture na vore wat bestuur en gekoördineer moet word. Organisasies moet deurentyd transformeer deur af te skaal, te herstruktureer en die eie identiteit te rekonstrueer. Die konsep van liminaliteit verskaf 'n model waarmee insig in hierdie proses verkry kan word (Küpers 2011:48-49).

Dit is belangrik om in te sien dat lidmate van die drie Afrikaanse susterskerke polities as etniese groep met 'n verlede, en godsdienstig as lidmate van die Afrikaanse kerke, op verskeie vlakke gedwing word om in die liminale ruimtes van die struktuur te beweeg. Ons leef trouens nou reeds geruime tyd in ' $n$ liminale staat, en die gevolg daarvan is ontwrigting, onsekerheid, 'n gebrek aan sosiale kohesie en die verlies van wedersydse vertroue, lojaliteit en toewyding (vgl. Küpers 2011:49). Die druk lei verder tot die oplos van identiteit, dubbelsinnigheid en onbepaaldheid. Gemeet teen die bykans onwankelbare massiwiteit van strukture in die vorige bedeling waarvan ons nog duidelike herinneringe het, is die huidige ontwrigting vir sommiges so groot dat hulle daarna teruggryp en probeer om iets te bestendig deur die Bybels-Reformatoriese teologie en die kerklike strukture as anker te gebruik. Die strukture is egter agterhaal en is onherroeplik aan die verander. Die kerk kan nie bly soos vroeër nie. Dit moet transformeer soos dit deur die liminale ruimtes beweeg, sodat dit aan die einde van hierdie rituele oorgang funksioneel in pas kan wees in die web van verhoudings waarbinne die kerk moet leef en werk.

Een van die onbekende realiteite waarmee die Hervormde Kerk as gevolg van 'n lang tyd van (selfopgelegde) isolasie gekonfronteer word, is die kwessie van pluralisme op kerklike en algemeen-godsdienstige terrein. Op hierdie gebied is ons babas in die bos. Eck (2007:744) verwys hierna wanneer sy die twee belangrikste uitdagings by die studie van godsdiens uitlig as godsdienstige ekstremisme en religieuse pluralisme. In 'n bespreking van godsdienstige pluralisme as 'n teologiese kwessie wys sy uit dat teologiese diskoers nie privaat is nie, maar openbaar (Eck 2007:767). Die fokus van die teologiese argument is op die geloofsgemeenskap waarbinne en waarvoor die teologie bedryf word. Dit stem ooreen met 'n vroeër uitspraak van Van Zyl dat die teologie meestal kerklike teologie is. Nogtans is dit deel van die teologie se taak om van die verskuiwende dinamika van godsdiens in 'n snel veranderende wêreld kennis te neem en om evaluerend daarby betrokke te bly (Eck 2007:773).

Tiplady (2003) bied 'n interessante nuwe moontlikheid vir 'n nuwe benadering tot struktuur in organisasies. Teenoor die voorstelling van 'n gestruktureerde en ordelike samelewing blyk die werklikheid dikwels deurmekaar, onstuimig, chaoties. Entropie, of die neiging na wanorde en kompleksiteit, is oral merkbaar. Vanuit die chaos-teorie wat aanvanklik in die natuurwetenskappe ontwikkel is as verstaansmodel om patrone van orde en wanorde te verklaar, kom die gedagte na vore dat orde nie van buite kom nie, maar dat die natuur in 'n proses van selforganisasie patrone vorm (Tiplady 2003:2; Overman 1996). Die konsep van 'fraktale' ([fractals] bv. sneeuvlokkristalle) word gebruik om te verduidelik hoe chaotiese sisteme op makro- en mikrovlak eenderse ordelike patrone vertoon. Fraktale het 'n ingewikkelde ontwerp, maar vertoon 'n eendersheid op verskillende skale. Volgens Tiplady (2003:5; kyk ook na Levy 1994:172) kan hierdie waarneming vrugbaar in organisasies gebruik word om dit wat op klein skaal blyk te werk ook op die groter skaal te implementeer. Toegepas op die kerk beteken dit dat patrone geïdentifiseer moet word by gemeentes wat groei in plaas van krimp en dat daardie patrone na die organisasie as geheel uitgebrei moet word. Tiplady (2006) onderskei die volgende moontlike stappe om organisatoriese 'chaos' teen te werk (Kassie 1).

KASSIE 1: Nuwe benadering tot organisasiebestuur.

\begin{tabular}{|ll|}
\hline Huidige benadering & Nuwe benadering \\
Klassiek of wetenskaplik: & Kompleks-aanpasbaar: \\
- probeer beheer uitoefen & - soek na die patroon \\
- probeer voorspel & - pas aan by die omgewing \\
- soek na sekerheid & - veek na geleentheid \\
- verander mense se optrede & - oefen invloed uit op die geheel \\
- bestuur die onderafdelings & - laat spontane organisering toe \\
- organiseer & - moedig verskillende benaderings aan \\
- soek na die beste manier & - soek verskeidenheid. \\
- soek eeheid. & Bron: Tiplady, R., 2006, Managing change in dynamic non-linear systems, viewed 12 March \\
2013, from http://www.tiplady.org.uk/pdfs/dynamicnonlinearchange.pdf
\end{tabular}

2013, from http://www.tiplady.org.uk/pdfs/dynamicnonlinearchange.pdf 
Die hooftaak van kerklike leiers is om nou hierdie proses aan lidmate te verduidelik en hulle sover moontlik op die pad van transformasionele oorgange saam te neem. Hulle moet weet ons 'dans op die drumpel' en beweeg deur die liminale ruimtes. Soms moet ons wag om ons dinamiese ekwilibrium te herwin voordat ons kan verder gaan (Küpers 2011:53). Tog is ons almal in dieselfde communitas en behoort ons mekaar vas te hou - nie net as maatreël teen moedeloosheid nie, maar ook omdat ons glo dat die energieskeppende werking van God se Gees ons na nuwe ruimtes van verstaan en aksie sal lei.

\section{Gevolgtrekking: Die sjibbolet van regsinnigheid}

Dit is duidelik dat ons tans, benewens strukturele en institusionele probleme, met verskillende teologiese menings in die kerk te doen het. Die wyse waarop die Hervormde teologie as Bybels-Reformatories by sekere teoloë en groepe in die Kerk verstaan word, dui daarop dat dié begrip as 'n dogmaties-ideologiese a priori ingespan word, 'n soort sjibbolet by die toets vir regsinnigheid. Dit is in stryd met die Reformatoriese vryheid wat die Hervormde teologie deurgaans vir sy teoloë en akademici gehandhaaf het. Sola scriptura kan nie Reformatories so verstaan word dat met die een hand vryheid gegee word om die Bybel as enigste bron van geloof wetenskaplik te ondersoek en met die ander hand dit weer weggeneem word nie. Die beginsel scriptura sui ipsius interpres is ' $\mathrm{n}$ groot sondebok in die verleiding om teologie in 'n geslote sisteem te beoefen. Die gevaar hiervan is dat predikante wat hierdie standpunt handhaaf en die lidmate wat hulle volg, daartoe beweeg word om:

- te dink hulle weet presies wat God wil hê

- te dink dat God klaar bereik het wat Hy wil doen sodat hulle met 'n gestolde werklikheidsbegrip opereer

- te weier om verandering toe te laat of self te verander.

Die Beswaarskrif teen Besluit 54 van die 69ste Algemene Kerkvergadering van 2010 adem hierdie gees. Dit verteenwoordig meer as 'n flirtasie met die gereformeerde ortodoksie. Dit is ' $n$ intieme aanleun by 'n sisteem wat indruis teen die Hervormde teologiese tradisie soos dit van die vroegste tyd af verstaan is (kyk na Oberholzer 1993:873879 vir 'n bespreking van die sienings van Goddefroy 1889; Brandt 1925; Oosthuizen 1934 en van Zyl 1942). Dit is na my mening 'n ondermyning van die Jesus-saak soos uitgedruk in die evangelies. Dit ondermyn ook die bedoeling van die Reformasie om in die gees van die Renaissance terug te gryp na die bronne en so aan die versmorende houvas van dogma in die Rooms-Katolieke Kerk van die laat-Middeleeue te ontsnap.

Kritiese Bybelwetenskap adem die gees van die Reformasie deur juis teen ideologiese kruiping waaksaam te wees. Miskien behoort die grootste aanklag teen die kritiese teologie tans nie te wees dat dit van reformatoriese beginsels afwyk nie, maar dat dit nie waaksaam genoeg was teen dogmatiesideologiese kruiping nie.
Die teologie is ' $n$ kreatiewe onderneming omdat dit op die transendente, nooit voorhande God fokus wat altyd groter en meer is as taalkundige formulering. Dit is die taak van die teologie om 'n produk vir die Kerk te lewer wat verhoed dat gelowiges in die geliefde, geykte retoriek begin glo en hulle hou by 'n lewende verhouding met God self. Hiervoor mag die model van liminale oorgange en egte communitas nuttig blyk.

\section{Erkenning Mededingende belange}

Die outeur verklaar dat hy geen finansiële of persoonlike verbintenis het met enige party wat hom nadelig kon beïnvloed in die skryf van hierdie artikel.

\section{Literatuurverwysings}

Beech, N., 2010, 'Liminality and the practices of identity reconstruction', Human Relations 64(2), 285-302. http://dx.doi.org/10.1177/0018726710371235

Beukes, J., 2012, 'Die hervormde middelgrond - 'n begrippeverheldering', Die Hervomer, November, bl. 8, 6

Beyers, J., 2013, 'Die roeping van die kerk', in Die Hervormer, besigtig 12 Maart 2013, by http://hervormer.co.za/gesprek/index.php/alle-bydraes/18-die-roeping-vandie-kerk.html

Bolton, M.J., 2009, “'A fragment of lost words”: Narrative ellipsis in The Great Gatsby', in M. Dickstein (ed.), Critical insights: The Great Gatsby, pp. 190-204, Salem, Pasadena.

Brandt, L.E., 1925, 'Onze tradities en gewoonten', Almanak voor de Nederduitsch Hervormde Kerk van Afrika 19, 106-117.

Charniawska, B. \& Mazza, C., 2003, 'Consulting as a liminal space', Human Relations 56(3), 267-290. http://dx.doi.org/10.1177/0018726703056003612

Cook-Sather, A., 2006, 'Newly betwixt and between: Revising liminality in learning to teach', Anthropology and Education Quarterly 37(2), 110-127. http://dx.doi. org/10.1525/aeq.2006.37.2.110

Davey, N., 2002, 'Hermeneutics and art theory', in P. Smith \& C. Wilde (eds.), A companion to art theory, pp. 436-447, Blackwell, London. http://dx.doi.org/ 10.1002/9780470998434.ch36

Douglas, M., 1973, Natural symbols: Explorations in cosmology, Pantheon Books, London.

Dreyer, T.F.J., 1985, 'Die dogmatiese binding van die prediking', HTS Teologiese Studies/Theological Studies 41(3), 378-386.

Dreyer, W.A., 1999, 'Tussen ortodoksie en vrysinnigheid', in D.J.C van wyk (red.), 20 ste eeu hervormde teologie, bl. 226-238, Sentik, Pretoria.

Eck, D.L., 2007, 'Prospects for pluralism: Voice and vision in the study of religion', Journal of the American Academy of Religion 75(4), 743-776. http://dx.doi. org/10.1093/jaarel//fm061

Franks, A. \& Meteyard, J., 2007, 'Liminality: The transforming grace of in between places', The Journal of Pastoral Care and Counselling 61(3), 215-222. Pmid:17958086

Gadamer, H-G., 1960, Wahrheit und methode: Grundzüge einer philosophischen hermeneutik, Mohr, Tübingen.

Gander, H-H., 2007, 'Erhebung der geschichtlichkeit des verstehens zum hermeneutischen prinzip', in G. Günther (red.), Hans-Georg Gadamer: Wahrheit und methode, bl. 105-126, Akademie Verlag, Berlin. http://dx.doi.org/10.1524/ 9783050050195.105

Goddefroy, M.J., 1889, De kerkkwestie niet een leer-maar een lewenskwestie, 2e druk, De Swart en Zoon, Den Haag.

Iser, W., 1980, The act of reading: A theory of aesthetic response, Johns Hopkins University Press, Baltimore. PMid:6993888

Jauss, H.R., 1982, Towards an aesthetic of reception, transl. T. Bathi, University of Minnesota Press, Minneapolis.

Kinoshita, Y., 2004, Reception theory, viewed 11 March 2013, from http://www. yumikinoshita.com/receptiontheory.pdf

Koekemoer, J.H., 1995, 'Die etos van die Nederduitsch Hervormde Kerk', HTS Teologiese Studies/Theological Studies 51(3), 876-880. http://dx.doi.org/10.4102/hts. v51i3.1447

Komitee van Steedshervormers, 2012, Steedshervormers, besigtig 12 Maart 2013 , by http://www.steedshervormers.co.za/images/dokumente/staat\%20van $\% 20$ belydenislank.pdf

Küpers, W., 2011, 'Dancing on the limen - embodied and creative inter-places as thresholds of be(com)ing: Phenomenological perspectives on liminality and transitional spaces in organisation and leadership', Tamara 9(3/4), 45-59.

Levy, D., 1994, 'Chaos theory and strategy: Theory, application, and managerial implications', Strategic Management Journal 15, 167-178. 
Lindsay, D.M., 2010, 'Organizational liminality and interstitial creativity: The fellowship of power', Social Forces 89(1), 163-184. http://dx.doi.org/10.1353/sof.2010.0068

Loader, J.A., 1978, 'Gedagtes oor gekontroleerde eksegese', HTS Teologiese Studies/ Theological Studies 34(1/2), 1-40.

Nederduitsch Hervormde Kerk van Afrika (NHKA), 2011a, Besluitebundel van die 69ste Algemene Kerkvergadering, Kerkargief, Pretoria.

NHKA, 2011b, Kerkorde van die Nederduitsch Hervormde Kerk van Afrika, soos gewysig volgens die besluite van die 69ste Algemene Kerkvergadering, Kerkargief, Pretoria.

NHKA, s.a., Apostolicum, besigtig geen datum, by http://www.nhka.org/index.php/ so-glo-ons-11/ekumeniese-belydenisse/apostolicum.html

Oberholzer, J.P., 1993, 'Die teologiese eie-aardigheid van die Nederduitsch Hervormde Kerk: Vrae en nuanses', HTS Teologiese Studies/Theological Studies 49(4), 870886.

Oberholzer, J.P., 1990, 'Ou-Testamentiese perspektiewe op die definisie van die prediking', HTS Teologiese Studies/Theological Studies 46(4), 647-655.

Oberholzer, J.P.,1999, 'Terug op die pad', in D.J.C. van Wyk (red.), 20ste eeu Hervormde teologie, bl. 449-461, Sentik, Pretoria.

Oosthuizen, C.W., 1934, 'Wat is die standpunt van die Ned Herv kerk?', Almanak vir die Nederduitsch Hervormde Kerk Van Afrika 28, 153-157.

Overman, E.S., 1996, 'The new sciences of administration: Chaos and quantum theory', Public Administration Review 56(5), 487-491. http://dx.doi.org/10.2307/977050

Pelser, G.M.M., 1985, 'Die verhouding bybelse teologie en dogmatiese teologie', HTS Teologiese Studies/Theological Studies 41(3), 339-350.

Pont, A.D., 1999, 'Die Bybels-Reformatoriese teologie: Omtrek en inhoud', in D.J.C. van Wyk (red.), 20ste eeu Hervormde teologie, bl. 199-211, Sentik, Pretoria.

Sandvoss, C., 2011, 'Reception', in V. Nightingale (ed.), Handbook of media audiences, pp. 230-250, Wiley-Blackwell, London. http://dx.doi.org/10.1002/ 9781444340525.ch11

Smith, D.J., 1985, 'Bybelse teologie - dogmatiese teologie', HTS Teologiese Studies/ Theological Studies 41(3), 351-363.

Sturdy, A., Schwarz, M. \& Spicer, A., 2006, 'Guess who's coming to dinner? Structures and uses of liminality in strategic management consultancy' Human Relations and uses of liminality in strategic management consultancy'
59(7), 929-960. http://dx.doi.org/10.1177/0018726706067597
Tiplady, R., 2003, Letting go: Chaos theory and the management of organisations, viewed 12 March 2013, from http://www.tiplady.org.uk

Tiplady, R., 2006, Managing change in dynamic non-linear systems, viewed 12 March 2013, from http://www.tiplady.org.uk/pdfs/dynamicnonlinearchange.pdf

Turner, V., 1969, The ritual process: structure and anti-structure, Aldine Publishing Co. Chicago.

Van Aarde, A G 1981. 'Die kritiek op die fundamentalisme, ' $n$ vorm van teologiese libertinisme', HTS Teologiese Studies/Theological Studies 37 (4), 6-21.

Van Aarde, A.G. \& Pelser, G.M.M., 2001, 'n Oop en vry teologiese debat met werklike diepgang', HTS Teologiese Studies/Theological Studies 57(1/2), 1-48.

Van Aarde, A.G. \& Groenewald, J., 2006, 'The role alternate states of consciousness played in the baptism and eucharist of the earliest Jesus-followers', HTS Teologiese Studies/Theological Studies 62(1), 41-67.

Van Gennep, A., [1909] 1960, The rites of passage, transl. M.B. Vizedom \& G.L. Caffee, Routledge and Kegan Paul, London.

Van Staden, P., 1991, 'Compassion - the essence of life: A social-scientific study of the religious symbolic universe reflected in the ideology/theology of Luke', HTS Teologiese Studies/Theological Studies, suppl. ser. 4.

Van Staden, P., 2001, 'Doop as ritueel van status-transformasie', HTS Teologiese Studies/Theological Studies 57(1/2), 576-592.

Van Zyl, F.J., 1999, 'Aktualiteit en neerslag van Karl Barth se versoeningsleer in ons teologie', in D.J.C. van Wyk (red.), 20ste eeu Hervormde teologie, bl. 406-419, Sentik, Pretoria.

Van Zyl, F.J., 1942, 'Ons kerk en ons volk', Almanak vir die Nederduitsch Hervormde Kerk Van Afrika, 58-62.

Velthuyzen, G.C.,1984, 'Skrifbeskouing in die Nederlandse Geloofsbelydenis', HTS Teologiese Studies/Theological Studies 40(4), 84-92.

Velthuyzen, G.C., 1985, 'Wat is die woord van God - skrif, belydenis, prediking?', HTS Teologiese Studies/Theological Studies 41(3), 364-371.

Waskul, D.D., 2005, 'Ekstasis and the internet: Liminality and computermediated communication, New Media and Society 7(1), 47-61. http://dx.doi. org/10.1177/1461444805049144

Wikipedia, n.d., Iceberg theory, viewed 11 March 2013, from http://en.wikipedia.org/ wiki/iceberg_theory 